Marquette University

e-Publications@Marquette

$1-1-1997$

\title{
The Flexible Executive Mindset: How Top Management Should Look at Tomorrows Markets
}

Gene R. Laczniak

Marquette University, eugene.laczniak@marquette.edu

Robert F. Lusch

University of Oklahoma Norman Campus

Accepted version. Journal of Consumer Marketing, Vol. 14, No. 1 (1997): 60-81. DOI. (C) 1997

Emerald. Used with permission. 


\title{
The Flexible Executive Mindset: How Top Management Should Look at Tomorrow's Markets
}

\author{
Gene R. Laczniak \\ Sanders Professor of Marketing, Marquette University \\ Milwaukee, WI \\ Robert F. Lusch \\ Walton Professor of Marketing and Accounting, \\ University of Oklahoma \\ Norman, OK
}

\begin{abstract}
:
The need for management to better anticipate the future is the urgent message currently being advocated by consultants in strategic market planning. Uses a survey of high-level managers from Fortune 1,000 corporations to illustrate the advantages of cultivating a flexible mindset concerning environmental trends and their strategic marketing implications. Reviews projected developments in the economy, technology, ecology and the social/political environments that are expected to occur by 2005 . Discusses appropriate marketing responses to these trends.
\end{abstract}

Keywords: Competitive strategy, Environmental scanning, Forecasting, Strategic marketing

\section{Introduction}

In their recent book, Competing for the Future, strategists Gary Hamel and C.K. Prahalad write, "Any company that is a bystander on the road to the future will watch its structure, values, and skills become progressively less attuned to industry realities ...Given that change is inevitable, the real issue for managers is whether the 
change will happen belatedly, in a crisis atmosphere, or with foresight, in a calm and considered manner" (Hamel and Prahalad, 1994a). In their research, Hamel and Prahalad reveal the typical top managers' orientation to the future is not a flattering one. They assert that the usual management approach to the future conforms to what they call the "40-30-20" rule. The essence of this rule is as follows (Hamel and Prahalad, 1994b): senior executives typically spend 40 percent of their time looking at issues external of their company. Of that time, only 30 percent is spent contemplating questions that will impact their organization further than three years into the future. And of that time, no more than 20 percent is spent attempting to build a collective view of the future that will shape current market strategy. Therefore, top managers are spending less than 3 percent of their efforts (40 percent $\times 30$ percent $\times 20$ percent $=2.4$ percent) analyzing the long-range future and exploring its possible implications for their products and markets. This relative lack of a future-directed perspective is likely one of the tragic flaws of the current managerial mindset. Given the demonstrably rapid pace of external change, if top managers are going to lead and motivate strategic initiatives for their organization, they need to more systematically consider the nature of possible future options (Henkoff, 1990).

This paper has several objectives. First, it will demarcate the need for future- oriented strategic thinking and what such future directedness realistically can and cannot do in terms of strategic market planning. Second, it will argue the importance of cultivating a flexible managerial mindset that leads to a systematic vision for the future. Finally, it will utilize an exploratory forecast, based on the collective vision of 54 high level executives, in order to illustrate how such exercises can help give shape to the strategic directions of company markets.

\section{The need for future-oriented strategic thinking}

It is sometimes said that there are three marketing styles. Style 1 tries to take customers where they do not want to go; Style 2 painstakingly researches every consumer want and preference and then attempts to react to those imputed needs; and Style 3 leads customers to products which satisfy the needs that customers have not yet fully realized. The first type of marketing style (taking customers where they do not want to go) is reminiscent of the ageold selling concept (Kotler, 1994). Such marketing organizations 
develop a product, launch it with a big time advertising budget, pitch it intensively with their salesforce, and assume it will satisfy customer needs. Unfortunately, the economic landscape is littered with failed companies which have adopted this sell-driven philosophy (Hartley, 1995). The second type of marketing style (often market-research driven) is reminiscent of organizations that suffer from what Levitt (1975) called "marketing mania." These companies are so busy responding to every consumer wish and whim, tinkering with each incremental modification, that they fail to see the bigger picture and often abdicate their role as product visionaries. This is very much the sort of corporation that Hayes and Abernathy (1980) described as part of their famous "managing our way to economic decline" thesis. Such companies are so taken with the incrementalism of adjusting current product offerings that they lose the ability to innovate boldly. They are stuck in the rut of modifying existing products in existing markets (Aaker, 1992). The future-oriented marketing style (the one which leads consumers) realizes the importance of selling and market research, but in addition, keeps abreast of what competitors are doing. Most importantly, these companies look to the future with a variety of forecasting techniques in order to predict and understand possible changes in technology, the economy, demographics, lifestyle, and public policy - the essential factors that will create and shape the new products and markets of the future.

Consider the following classic example of a futures-oriented marketing style (Hamel and Prahalad, 1994b). It deals with Chrysler Corporation's rationale for developing the minivan in the early 1980s. At the time, the concept of the passenger minivan was so radically different from previous vehicles that it was not deducible from traditional customer surveys. This was because few customers were able to articulate a design so dramatically in contrast with the standard station wagon. From a pure engineering standpoint, the minivan idea had been explored by Ford but, because there was no track record for such a vehicle, the concept was abandoned as a likely financial pitfall. Ford's fall back strategy was simply to continue to sell slightly improved stationwagons. In contrast, Chrysler looked at global, evolving consumer needs and ascertained the probability of a successful minivan based on an educated reading of the changing consumer market. They predicted the consumer's desire for greater cabin and cargo space; the suburban lifestyle which called for carpooling with multiple children plus greater road time; the 
acceptance by female drivers of function over traditional station wagon styling, and they developed the technological ability to place a van body type on automobile frame (Hamel and Prahalad, 1994b). In short, Chrysler successfully visualized the future.

The point is that the winning organizational approach for dealing with the future involves marketing that looks to fulfill future consumer needs by forecasting lifestyle changes, shifting social conditions and emerging technology. The current style of management, which allots less than 3 percent of top management time to anticipating the future, is unlikely to secure tomorrow's competitive advantage in the marketplace. Thus, most managers need to recommit to examining the future more carefully.

\section{What a futures orientation can and cannot do}

To the casual reader the term "futures orientation" might suggest a sensitivity about the future which allows its prediction; however, accurate prediction is not the primary or only purpose for managers cultivating a future directed perspective. Why? Accurate prediction of the future business environment, five years out and beyond, is a very uncertain endeavor. The folly of trying to predict the future accurately can be illustrated by looking at the track record of the so- called sages who attempted to forecast various dimensions of the economic landscape several decades into the future from their vantage point in the late 1930s and 1940s (Olesen, 1974). Writing in magazines such as Harpers, the Atlantic, Time, and Newsweek about life 30 years down the road, the consensus forecasts look ridiculous in the sober light of reality. For example, concerning US housing, there was relatively surprising agreement that, by the 1990s, the majority of houses would be prefabricated and erected in hours; rooms could easily be rearranged, added or subtracted; plastic and light metal materials would constitute the bulk of fabrication; housing prices would have consistently decreased over time due to enormous economies of scale.

Perhaps the most acclaimed contemporary futurist is Alvin Toffler, author of the pathbreaking book Future Shock (1970) and recent best-seller The Politics of the Third Wave (Toffler and Toffler, 1995). While Toffler's general message about the importance of

Journal of Consumer Marketing, Vol 14, No. 1 (1997): pg. 60-81. DOI. This article is $\subset$ Emerald and permission has been granted for this version to appear in e-Publications@Marquette. Emerald does not grant permission for this article to be further copied/distributed or hosted elsewhere without the express permission from Emerald. 
cultivating a future orientation has made a lasting impression in some circles, Toffler's ability to predict specific business developments as short as ten years into the future is demonstrably poor. Forecasts such as the throw-away paper wedding gown and the projected popularity of 3-D photography did not materialize as intimated in Future Shock (Toffler, 1970). Moreover, most of Toffler's predictions about the increasing fragmentation of automobile designs and models (using Ford Motor Company's Mustang as a primary example) look rather lame as Ford's current efforts are aimed in the opposite direction. Currently, Ford strives for standardized models that are "world brands" such as those sold in the USA under the nameplates Ford Contour and Mercury Mystique (Business Week, 1995). Still, the fundamental messages advocated by Toffler, including the need for a flexible mindset and an abiding orientation to the future, continue to be contemporaneously valid.

As the above failed projections illustrate, the likelihood of consistently predicting the future will not be realized. Often, it is the unanticipated event or the breakthrough technology that revolutionizes societal and economic developments. For example, during the 1980s, the legion of expert analysts in the US intelligence community were unable to anticipate the fall of the Berlin Wall, the disintegration of the former Soviet Union or the rapid embrace of capitalism by Middle and Eastern Europe. Thus the purpose of a futures orientation is not so much to predict the future as it is to get managers to think more about what the future could hold (Laczniak and Lusch, 1977). In short, a futures orientation by managers is intended to contribute to the more modest organizational objectives of:

- making more explicit the assumptions that management presently holds about future developments,

- anticipating possible or alternative future events which will affect the business,

- tracing potential consequences of important current developments into the future,

- $\quad$ shaping and guiding current decisions of management that might impact future organizational operations.

Journal of Consumer Marketing, Vol 14, No. 1 (1997): pg. 60-81. DOI. This article is $\subset$ Emerald and permission has been granted for this version to appear in e-Publications@Marquette. Emerald does not grant permission for this article to be further copied/distributed or hosted elsewhere without the express permission from Emerald. 
Thus, the end goal of a futures orientation is to enable management to develop a flexible, managerial mindset that will better allow managers to cope with a dynamic future environment by visualizing its possibilities for the organization's products and markets.

\section{The importance of a flexible managerial mindset}

As described above, futurists cannot be awarded stellar scores for the accuracy of specific projections. However their logic for paying attention to the future, because sensitivity to it will allow for smoother response to change, represents thinking that is both prudent and progressive.

Consider that there are two basic ways to increase ROI (rate of return on investment) (Hamel and Prahalad, 1994c). Improvement comes by increasing the numerator (net income) or reducing the denominator (the amount of capital employed). In the case of the numerator, the effort of management is directed at increasing sales and the revenue stream. In the case of denominator management, the idea is to downsize investments, assets employed, or number of employees while generating the same level of productivity. Too many 1990s executives manage by "downsizing, decluttering, delaying, and divesting" (Hamel and Prahalad, 1994c). This is a pessimistic approach to the future. The more optimistic, futures-oriented approach is "numerator management." With this perspective, management cultivates a concern not only for today's customers and competitors but for those who will likely be customers and competitors in the future. Management scrutinizes not only present-day competitive advantages but also searches for the sustainable competitive advantages of tomorrow. They recognize not only existing core competencies but foresee the skills and capabilities that will lead to the core competencies of the future. This visioning requires a flexible managerial mindset.

We believe that, at minimum, a flexible mindset dictates that management create a platform for seeking additional information about the future, exploring the validity of current expectations about the future, challenging conventional wisdom, engaging in contingency planning and the aggressiveness to view change in the external

Journal of Consumer Marketing, Vol 14, No. 1 (1997): pg. 60-81. DOI. This article is $\subset$ Emerald and permission has been granted for this version to appear in e-Publications@Marquette. Emerald does not grant permission for this article to be further copied/distributed or hosted elsewhere without the express permission from Emerald. 
environment as an opportunity for profit. More about these characteristics follows in the next paragraph.

\section{Environmental scanning to prepare for the future}

Building alternative scenarios about the future may be the richest approach for analyzing future opportunities (Schoemaker, 1995). The advantages and disadvantages of creating scenarios in order to better understand future markets has been argued previously and elsewhere (Wilson, 1978). However, an essential step to that end is identifying basic trends of the future external environments of business. This means conducting an environmental scan. This step is followed by prioritizing the impact of those investigated trends on the organization and understanding what events, however uncertain, could significantly affect current products and markets.

To illustrate the process of utilizing a flexible mindset for thinking about the future, we conducted an exploratory environmental scan involving 54 top managers who responded to a battery of possible external trends that could effect the future of business organizations between now and 2005.

\section{This study: an exercise in flexibly looking at the future}

In order to generate a set of baseline projections about the future business environment, top managers of Fortune 1,000 corporations were surveyed. Such executives were considered to be expert by virtue of their position as organizational élites. They wield enormous economic influence, serve as boundary spanners with various external stakeholders and have access to salient company and industry information.

Our questionnaire consisted of approximately 120 statements which described possible environmental developments which could occur by the year 2005. The items were grouped in sets representing economic, technological, ecological, political, and social trends about the future. The specific trends evaluated were derived from a comprehensive search of the futures-oriented literature (e.g., Futurist Magazine) as well as numerous articles about the future of business which have appeared in the press over the past decade (e.g., Fisher, 
1990; Modis, 1994). A number of the statements included in the study had been revised, refined and utilized in other research efforts as this project represented a continuation of previous work that tapped the opinions of top managers concerning the future (Laczniak and Lusch, 1986). The survey, containing the over 100 trend projections, required the respondents to estimate the likelihood of occurrence of each trend (on a six-point scale) where the likelihood estimate ranged from 0 percent to 100 percent. In addition, the executives projected the organizational impact (high/medium/low) that each trend would have on their organization if in fact it occurred. This was important because some trends, if they happened, would have a larger organizational impact for some companies than others. For example, companies doing business in Asia would be more affected by "the opening of the Chinese market" (a possible trend) than firms with predominantly North American operations. Collectively, some trends (e.g., reduced funding for primary education) would be less potent for business in general than other sectors of the society (e.g., community public schools).

Fifty-four high level executives returned completed surveys ( $n=$ 54). Thirty-eight percent were filled out by CEOs. Another 41 percent by Fortune 1,000 vice-presidents such as VP-Planning or VPMarketing. All respondents were high-ranking managers.

What about the response rate? These questionnaires were sent to the CEOs of the Fortune 1,000 corporations hoping to generate replies from between 50 to 150 high level executives. The authors felt that the collective view of such a group about the future business environment would be sufficient to provide a benchmark against which other managers might test their own assumptions about the future. Although more responses would have been desirable, the authors were not especially concerned about the relatively low response rate by these top managers as the survey was never intended to be a projectable sample. Response rates by high-ranking managers to surveys have been historically low (Laczniak et al. 1994). Pressures on top managers to provide information to external sources are extraordinary. Typically top management of major organizations seldom reply to surveys unless they are internal to the organization, required by law or of inherent personal interest to the manager recipient. Additionally, if management consultants are correct in stating that senior managers spend only a small proportion of their

Journal of Consumer Marketing, Vol 14, No. 1 (1997): pg. 60-81. DOI. This article is $\subset$ Emerald and permission has been granted for this version to appear in e-Publications@Marquette. Emerald does not grant permission for this article to be further copied/distributed or hosted elsewhere without the express permission from Emerald. 
time thinking about the future, then one would expect that most senior managers would feel uncomfortable completing a survey of the type we developed. In fact, some might be intimidated or embarrassed by queries concerning not only the future economy but also technology, ecology, political and world social trends. Because of this, one might expect that the 54 managers (the CEOs or their top management designates) who chose to reply are providing special testimony to their interest in, and concern for, the future.

More importantly, these managers represent an ex officio expert sample because such top executives have a fiduciary responsibility to plan for the future of their organizations. Thus, whether these executives have been outward looking or not, it would be expected that they have determinable views about the future business environment because they must make current decisions which will affect the ability of their organizations to compete a decade from now and beyond. By looking at the collective opinions of such an assembly of business leaders, this survey exercise makes explicit the assumptions that a key group of managers, in the aggregate, holds about the future. An examination of this information also represents an opportunity for other managers to compare and explore their current expectations. A more detailed look at the environmental forecast and how the information can be used to stimulate a flexible managerial mindset is discussed below.

\section{The findings: a senior management perspective on the future}

For each external environment, readers should examine the responses regarding the likelihood of occurrence for each item within the environmental category. As noted earlier, this collective expectation represents an explicit profile of the views that 54 highlevel managers hold about various possible future events. To the extent that the results are consistent with the reader/manager's personal expectations, the findings confirm a future business environment for which their organization should be strategically planning (i.e., the main expected scenario). To the extent the collective assessment represents a different expectation than that held by the reader/manager, perhaps this differing perception is due to the uniqueness of one's particular industry. Alternatively, deviant projections may represent reason to think further about one's own

Journal of Consumer Marketing, Vol 14, No. 1 (1997): pg. 60-81. DOI. This article is @ Emerald and permission has been granted for this version to appear in e-Publications@Marquette. Emerald does not grant permission for this article to be further copied/distributed or hosted elsewhere without the express permission from Emerald. 
current expectations about the future, i.e., to question one's assumptions via contingency planning. In addition, each item of the survey, as noted earlier, also offers an organizational impact (OI) score (high/medium/low) indicating the likely importance of the trend on their business organization, if it occurs. In situations where the collective judgment is that a particular low probability trend will have a high or medium OI for the majority of respondents, these trends imply an opportunity for conducting contingency planning for the unexpected because of the projected organizational ramifications if the event happens. For example, the data in this survey suggest that a worldwide shortage of oil before 2005 is an unlikely event. However, if this event should occur, the impact on the typical corporation will be high. Thus this possibility seems to suggest a need for explicit contingency planning. Figure 1 represents a summary of the overarching planning approach that managers might use in responding to individual trends/projections with high and low probabilities of occurrence in conjunction with OIs which are either high, medium, or low.

Next, the trend projections for the five major external business environments, as perceived by our sample of 54 business leaders, are presented. This data serves as an exploratory environmental scan of key future environments that may shape future marketing decisions. The accompanying commentary illustrates how such information might contribute to flexible managerial thinking about future markets, products and services.

\section{[Figure 1]}

\section{World and US economy in 2005}

Twenty-four possible trends dealing with various aspects of the future world and US economy were evaluated by the manager respondents (see Tables I and II). Perhaps the most interesting general perception concerning the future economic environment was that doomsday possibilities were wholeheartedly rejected. The vast majority of the respondent/managers saw an extremely low likelihood (20 percent or less) that a worldwide global depression would occur, that unemployment would exceed 10 percent in most developed countries or that inflation would exceed 12 percent in the most developed countries (see Tables I and II, items E1, E3, E8). If there

Journal of Consumer Marketing, Vol 14, No. 1 (1997): pg. 60-81. DOI. This article is @ Emerald and permission has been granted for this version to appear in e-Publications@Marquette. Emerald does not grant permission for this article to be further copied/distributed or hosted elsewhere without the express permission from Emerald. 
was a surprise in these economic projections, it had to do with the surprisingly large portion of the respondents who predicted that by 2005 the Pacific Rim countries will exceed the European Union in their collective economic power (item E17). Sixty-three percent of the responding managers saw this outcome as having 60 percent or greater likelihood of occurring. Perhaps some of this perception was shaped in conjunction with the respondent's response to trend item E12 which had 72 percent of the top managers predicting (with 60 percent or greater likelihood) that "China will emerge as a major economic power." Other economic trends receiving relatively strong support for their occurrence were item E13 involving "worldwide sourcing for materials and components gravitating to low cost provider nations" and item E9 projecting that large, corporations would focus more heavily on controlling their labor costs especially with automation. Perhaps the likely occurrence of these two trends also accounted for the strength of trend item E20 whereby 88 percent of the sample suggested that, with a 60 percent or greater likelihood, the US workforce would grow increasingly diverse, as women, minorities, and immigrants would account for the majority of new workers. In other words, reductions in labor costs and the shift of higher-paying manufacturing jobs overseas would leave relatively more job opportunities for those demographic groups that have historically held the lower wage jobs in the USA. Importantly, all of these relatively high probability events were also generally seen as having a moderate to high impact on the organization.

\section{[Table I]}

In summary, looking across the two dozen possible economic trends, what emerges is a picture where the most dire economic possibilities are generally rejected and the greatest international market opportunities seem to be in the Pacific rather than Europe. In addition, the top management respondents predict a US corporate mentality that continues to be concerned about controlling cost by means of worldwide sourcing, experimentation with automation, and the integration of an increasingly diverse, but low-wage, workforce.

\section{[Table II]}

Journal of Consumer Marketing, Vol 14, No. 1 (1997): pg. 60-81. DOI. This article is $(\subset)$ Emerald and permission has been granted for this version to appear in e-Publications@Marquette. Emerald does not grant permission for this article to be further copied/distributed or hosted elsewhere without the express permission from Emerald. 
NOT THE PUBLISHED VERSION; this is the author's final, peer-reviewed manuscript. The published version may be accessed by following the link in the citation at the bottom of the page.

\section{Technology in 2005}

The sample of managers responded to a battery of 21 items describing the possible future of technology (Tables III and IV). A perusal of the responses suggests a connecting theme among the various items in the technology group that received relatively widespread support for occurrence. That theme might be characterized as centering on the advancement of information technology. The trend statements falling beneath this umbrella theme included projections for:

- comprehensive, interlocking databanks (item T1),

- the continued growth of the telecommunications, information and electronics industries (item T2),

- greater automation via computerized machine tools, robotics, and CAD/CAM (item T4),

- information technology leading to improvement in productivity by managers equal to at least 15 percent (item T9),

- an extremely high computer literacy rate among those members of the population under age 30 (item T10),

- the attainment of the information superhighway (item T16).

All of these environmental trends were projected by the majority as having a minimum likelihood of occurrence of 60 percent or greater. An examination of the individual items in Table IV suggests a degree of support substantially stronger in several instances (e.g., items T1 and T2). These widespread predictions for technology- driven developments could suggest an almost halo effect for technological advances except for the fact that the respondent/managers were discerning enough to disagree with a couple of currently very popular technology trends. Specifically, the majority saw little likelihood (20 percent or less) that further space missions (item T8) would provide a major economic boost to R\&D in corporations with related expertise or that high-speed rail systems (item T13) would significantly contribute

Journal of Consumer Marketing, Vol 14, No. 1 (1997): pg. 60-81. DOI. This article is $(\subset)$ Emerald and permission has been granted for this version to appear in e-Publications@Marquette. Emerald does not grant permission for this article to be further copied/distributed or hosted elsewhere without the express permission from Emerald. 
to the reduction of metropolitan traffic congestion. One trend, which was given only a medium likelihood of occurrence, involved artificial intelligence being increasingly used for middle-management decision making, and thereby eliminating a significant number of positions (item T15). But it garnered an extremely high organizational impact score if it should occur. Overall, there was a sense by the respondent/managers that organizations need to prepare for a sophisticated technoworld - where the computerized management of information and the oversight of employee productivity - is the dominant motif. Organizations not planning for such a general scenario are likely to find themselves at an extreme competitive disadvantage by 2005 .

\section{World and US Ecology in 2005}

The sample of top managers next reacted to a set of 13 items describing possible ecological trends in the physical environment by 2005 (see Tables V and VI). One discernable theme in their reaction to these ecologically-oriented items was the general prediction that environmental initiatives, such as additional legislation and the green marketing wave, were not likely to increase. For example, (item G13) the projection that a host of ecologically compatible

\section{[Table III]}

products and promotional appeals would dominate various product categories was seen as unlikely (likelihood 40 percent or less) by 64 percent of the responding managers. Similarly, the majority of manager/respondents foresaw new environmental restrictions (item G11) as unlikely (40 percent or less chance) to diminish the competitiveness of US business further. Perhaps the most telling embodiment of this anti-green theme (item G6) was that a majority of respondent/managers believed it was relatively unlikely (likelihood 40 percent or less) that consumers would be willing to accept higher costs in order to protect the environment. In short, the sample of top managers responding to this survey were skeptical of the staying power of many of the green initiatives and strategies that have been so popular in recent years (Denton, 1994). Even the scientifically demonstrable greenhouse effect (item G5) is seen by the majority as not likely to occur, and even if it does, it will have a low organizational impact on the typical corporation. The upshot of all of this is that the

Journal of Consumer Marketing, Vol 14, No. 1 (1997): pg. 60-81. DOI. This article is $\subset$ Emerald and permission has been granted for this version to appear in e-Publications@Marquette. Emerald does not grant permission for this article to be further copied/distributed or hosted elsewhere without the express permission from Emerald. 
currently popular notion of ecologically-driven competitive strategies is not well supported as managers envision the future business environment. At minimum, most managers responding to this survey doubt the long- lastingness of the emerging ectopia which the popular press has lovingly embraced. The "correctness" of this prediction has major implications for current organizational strategies which often involve developing and promoting ecologically benign products and services (Ottman, 1992). Interestingly, two trends seen as generally not likely to occur were the ones which garnered the highest OI scores if they were to happen. The first was the trend mentioned earlier concerning environmental regulations (i.e., if they happened, this would definitely impact organizations). Similarly, if in the unlikely event that worldwide shortages of oil occur, this too would have a dramatic organizational effect for the majority of organizations.

\section{[Table IV]}

\section{[Table V]}

\section{[Table VI]}

\section{The US social environment in 2005}

Eighteen items dealt with the social environment. Because of the disparate nature of these possible social trends (see Tables VII and VIII), a unifying theme was difficult to discern from the responses. In the spirit of cultivating a flexible managerial mindset, executives might take a closer look at the trend predictions which received a relatively high level of support and try to think about them as future opportunities or threats. Among the items receiving relatively high support for their likely occurrence and relatively high organizational impact ratings, we find the following possible threats:

\section{[Table VII]}

- Major concern for the quality of public education. (Among other things, this suggests that many businesses may be shorthanded

Journal of Consumer Marketing, Vol 14, No. 1 (1997): pg. 60-81. DOI. This article is $\subset$ Emerald and permission has been granted for this version to appear in e-Publications@Marquette. Emerald does not grant permission for this article to be further copied/distributed or hosted elsewhere without the express permission from Emerald. 
when it comes to securing an educationally qualified pool of labor in the future.) Eighty percent of respondent/managers saw this item (S2) as having an 80 percent or greater likelihood of occurrence. They also foresaw that the US labor force will become increasingly stratified into two tiers: the technological élites and a more common underclass of relatively low-paid clericals and service workers (S4).

- An AIDS epidemic costing billions in company health care costs and lost productivity. (Among other things, such a projection may provide impetus for organizations to more aggressively seek automation options, thereby reducing the size of their employee force. Alternatively, companies may switch to a workforce of part-time or seasonal employees who do not necessitate a full-time health benefits package.) Fifty-six percent of the respondents projected this development (item S5) to have an 80 percent or greater likelihood of occurrence.

- An increase in worker entitlements especially in the area of work flexibility. (This outcome may cause organizations to more rapidly shift production to countries outside the USA where employee benefits are significantly less than that which has been the norm in the USA. Fifty-three percent of the managers polled forecast this item (S3) as having an 80 percent or greater likelihood.

- Periodic job and career changes are the rule rather than the exception. (This outcome suggests that if organizations intend to retain employees over their lifetime, they will need to spend significantly more funds on employee training and development due to the dynamic nature of shifting job requirements and responsibilities.) Fifty-two percent of the respondents viewed this trend (S9) as having an 80 percent or greater likelihood of occurrence.

\section{[Table VIII]}

Among the richest opportunities for corporations is the projected support for two trends that have been unfolding for a number of years:

Journal of Consumer Marketing, Vol 14, No. 1 (1997): pg. 60-81. DOI. This article is @ Emerald and permission has been granted for this version to appear in e-Publications@Marquette. Emerald does not grant permission for this article to be further copied/distributed or hosted elsewhere without the express permission from Emerald. 
- The emergence of the information superhighway (item S13), which will allow individuals to commute to work electronically, as well as engage in many other social functions via their networked computer. These functions include electronic shopping, banking, trading securities, voting, getting medical diagnoses, and undergoing some forms of psychotherapy. (The ramifications of such a dramatic change in lifestyle are just beginning to be explored by many industries. However, the message that all organizations must examine their operations for compatibility with the so-called cyberspace revolution is clear.) Fifty-two percent predicted this outcome as having an 80 percent or greater likelihood.

- The targeting of the aging baby boomer market. (Consistent with item S16, this development includes notable economic opportunities for organizations with products or services in the areas of security systems, home entertainment, housekeeping services, home health care, vitamins, anti- aging cosmetics, travel services, investment advice, and adult education.) Fiftyfour percent of the managers projected an 80 percent or greater likelihood for this scenario.

In terms of a flexible management orientation, social trends probably represent the external dimension of business best suited for suggesting possible product and market opportunities. If there is any theme evident among the various social trends which received relatively strong support for occurrence, it would be that most of these projected developments are extensions of existing trends. This tendency of trend extrapolation is consistent with the pattern found in many environmental scans, especially when concentrating on social events. Nevertheless, such extrapolation of current and emerging trends forces organizations to think about the most logical implications of existing social developments for the future of their organization.

\section{US political environment in 2005}

The expert sample also reacted to 20 possible environmental trends linked to political aspects of the business environment (Tables IX and $X$ ). When looking across these trends for patterns of support, a number of interesting insights emerge.

Journal of Consumer Marketing, Vol 14, No. 1 (1997): pg. 60-81. DOI. This article is @ Emerald and permission has been granted for this version to appear in e-Publications@Marquette. Emerald does not grant permission for this article to be further copied/distributed or hosted elsewhere without the express permission from Emerald. 


\section{[Table IX]}

\section{[Table X]}

First, there is the projected continuation of some long-standing trends that have been in evidence since the mid 1970s. These include the forecasts that the elderly (65 and over) will accrue increased political power and that labor unions will continue to lose political influence (see items P5 and P7). Given that this general power shift has been in evidence over the past 20 years, one wonders how much more power the elderly can really amass or the union movement can lose. Nevertheless, the graying of the baby- boom generation, the enhanced clout of lobby groups such as the American Association of Retired Persons (AARP), as well as the continued shift of manufacturing/assembly employment south to Mexico or elsewhere off-shore adds credence to these projections. Approximately half of the responding managers ascribed an 80 percent or greater likelihood to the occurrence of these events.

However, a couple of other political trends that had been widely discussed and predicted in the 1980 s and early 1990 s received minimal support for their of occurrence. The majority of responding managers see it as relatively unlikely (likelihood at 40 percent or lower) that the USA will adopt an industrial policy (item P1) whereby the federal government economically assists preselected industries; or that foreign ownership of US real estate and financial securities will further complicate the ability to manage and control the US economy (item P12). The former prediction is consistent with the views of the current 1996 Congress concerning less management of the economy. The latter seems to reflect the emerging view that foreign investment does not equate to foreign control.

One trend nearly split the respondents right down the middle in terms of its likelihood of happening. Specifically, the respondent/managers were divided in terms of whether federal regulation of domestic US business will substantially increase (P3). On the other hand, 48 percent of respondents anticipated increased

Journal of Consumer Marketing, Vol 14, No. 1 (1997): pg. 60-81. DOI. This article is $\subset$ Emerald and permission has been granted for this version to appear in e-Publications@Marquette. Emerald does not grant permission for this article to be further copied/distributed or hosted elsewhere without the express permission from Emerald. 
environmental regulation by all levels of government, indicating substantial mandated constraints at least in this sector of public regulation (P11). Perhaps the lack of consensus over this item has to do with the diverse industry affiliation of the various responding executives. Importantly, this trend may be reflective of the dynamic attitude shift in the US citizenship itself which, in the 1992 national election, voted for the change, regulation and reform represented by President Clinton. Then, in 1994, the electorate supported the general deregulation and governmental cutbacks embodied in the Republican "contract with America." While items on the direction of regulation produced a net ambivalent reaction, to the extent that regulations changed, the organizational impact on corporations was perceived to be relatively high. Thus, possible pending legislation that affects business appears to be a fertile area for contingency- planning efforts. And more of this story will unfold with the policy outcomes of the 1996 US elections.

\section{Ethics and social responsibility in 2005}

Thus far, the commentary has focussed on relationships among the trends within the confines of a particular external environment. It is also important for managers to recognize patterns of trends which cut across the various business environments. This sensitivity is sometimes referred to as "pattern recognition" and it involves an aptitude that managers with a flexible mindset need to cultivate (Montgomery and Weinberg, 1979).

In this vein, one of the intriguing patterns that seems apparent from an examination of all 100-plus environmental trends is the general lack of support for occurrences which improve or enhance the ethical climate of business decision making. The details of this weak support for a moral approach to management are demonstrated by the following:

- Major efforts to further develop and refine international codes of conduct for multinational corporations are not projected as likely to occur (item E2). Sixty-two percent of the respondents project a 40 percent or less likelihood that this trend will occur by 2005. Perhaps even more striking is that approximately half the respondents forecast that if this trend did occur, it would have low organizational impact the operations of their own

Journal of Consumer Marketing, Vol 14, No. 1 (1997): pg. 60-81. DOI. This article is $(\subset)$ Emerald and permission has been granted for this version to appear in e-Publications@Marquette. Emerald does not grant permission for this article to be further copied/distributed or hosted elsewhere without the express permission from Emerald. 
NOT THE PUBLISHED VERSION; this is the author's final, peer-reviewed manuscript. The published version may be accessed by following the link in the citation at the bottom of the page.

companies. For those executives committed to shaping a more responsible business environment, predicted outcomes such as this must be very disheartening, especially as improved and comprehensive codes of conduct are regularly called for by observers of business as an important step in reforming the equity of the economic system (Murphy, 1989).

- There was surprisingly little support for the position that advancing technology will also create a climate of social and ethical problems (item T5). Almost half the sample (48 percent) saw the likelihood of this occurrence as having a 40 percent or less probability. Equally problematic was the fact that 46 percent of the respondents noted that even if such an occurrence happened, its impact on their own organization would be low. Given the rapid advances along all of the major frontiers of technology - computing, electronics, information networks, artificial intelligence, etc. - it seems surprising that most managers do not envision a significant downside to these technological breakthroughs. Given the concerns about technology expressed in the press, especially having to do with issues of personal privacy via computerized information files, the displacement of workers due to automated technology, and the moral questions inherent in emergent biotechnology, the lack of recognition by the respondents concerning technology dysfunction is notable. Perhaps this lack of caution can be explained by the notion that managers see the technological environment as one of the few external sources of solutions, as opposed to the other external environments, which often become the breeding grounds of problems that society and business must subsequently deal with.

- There is relatively strong disagreement with the postulation that consumers will accept higher costs in order to protect the physical environment (item G6). The particulars of this issue were mentioned earlier and it apparently captures some of the managerial skepticism that has crystallized about the economic costs of ecological initiatives (Colford, 1994). However, such forecasts run counter to a number of current social movements, especially in Europe, where political parties espousing the "green movement" have amassed significant influence in setting ecological priorities in government policy.

Journal of Consumer Marketing, Vol 14, No. 1 (1997): pg. 60-81. DOI. This article is @ Emerald and permission has been granted for this version to appear in e-Publications@Marquette. Emerald does not grant permission for this article to be further copied/distributed or hosted elsewhere without the express permission from Emerald. 
- There is uncertainty about the continued appointment of more outside corporate directors who would represent stakeholder groups such as labor, consumers, and the host community (item P4). Except for the aforementioned improvement of ethics codes, the reform of corporate boards has been one of the most commonly recommended solution for the enhancement of ethical behavior by business organizations (Schellhardt, 1991). While 28 percent of the respondents see an 80 percent or greater likelihood that the movement toward outside directors will continue, it is notable that 35 percent of respondents project the likelihood of this trend at 40 percent or less. If this ambivalence about the reform of business at the board of directors level accurately reflects the future environment, it surely raises questions about the pace of business reform and the viability of the reinvention of business accountability that has been called for (Barton, 1995).

- The majority of the respondent/managers do not expect that socially responsible businesses will thrive in the future due to consumers who seek out companies that operate with ethics and integrity (item S17). In fact, 54 percent of the respondents see a 40 percent or less likelihood that this trend will occur by 2005. Moreover, even if it does occur, more than 40 percent expect that the development would have low organizational impact on their own company. That the responding business leaders do not see a competitive advantage for those organizations that operate with a high moral ethic, is most disturbing. The only positive interpretation of this particular projection might be that managers see this development (if it occurs) as having low organizational impact perhaps because they perceive their own organizations as already operating with high ethical ideals.

Given widespread public criticism about the ethical performance of business organizations (Laczniak et al., 1995), it is surprising that so most of the items which reflect such dimensions generally receive relatively lower support for their occurrence than many of the other trends included in this survey. 
NOT THE PUBLISHED VERSION; this is the author's final, peer-reviewed manuscript. The published version may be accessed by following the link in the citation at the bottom of the page.

\section{Preparing for the future}

As suggested by Figure 1, managers need to incorporate into their strategic plans the trends they perceive as likely to occur and which will have a high to medium impact on their organization if they occur. To facilitate this process, a list of the trends which collectively received a mean probability rating of 60 percent or greater and a mean organizational impact rating of 3.0 or higher was developed. Only 17 of all the trends met this criteria. They are shown in italics in the respective tables where the statistical results were previously listed. These trends represent a set of core planning premisses for most organizations. An organization should have a fairly strong reason for ignoring any of these trends. The 17 key trends are: T1, T2, T6, T9, T10, T12, T16, E1, E12, E13, E17, E20, S2, S3, S4, P11, P15.

However, the flexible manager should keep in mind more than just the high probability trends. If an external trend is unlikely to occur but it has a high organizational impact if it happens, it should be part of the firm's contingency planning. This is good business practice and it will help the manager to avoid a considerable amount of future shock, but not all of it.

As emphasized earlier, the totality of the future in unknowable. Often the biggest surprises that need to be addressed happen when a trend projected as both unlikely and of low organizational impact does indeed occur and actually has a high organizational impact. Such events are perceived as so remote, both in terms of occurrence and ramifications, that they are ignored. When they do occur, managers are in a state of shock. Imagine asking the CEOs of most Fortune 500 companies in 1950 what would be the likelihood and impact of every manager and many employees possessing their own computer. This was the year when the total worldwide market for computers was seen as in the hundreds. Most managers would have projected this eventuality as virtually impossible. And if it were to occur, it would probably be perceived as having a low impact because at the time computers were simply viewed as computational machines. How could such devices help a secretary, salesperson, advertising executive, or truck driver? The organizational impact would be undoubtedly low!

For this reason we urge managers to also review the list of lowlikelihood events that were seen as having low organizational impact.

Journal of Consumer Marketing, Vol 14, No. 1 (1997): pg. 60-81. DOI. This article is $\subset$ Emerald and permission has been granted for this version to appear in e-Publications@Marquette. Emerald does not grant permission for this article to be further copied/distributed or hosted elsewhere without the express permission from Emerald. 
No better illustration occurs in this survey than with the set ecological trends (Table $V$ ) which were generally seen as low likelihood and also of low organizational impact. If these unlikely events do occur and have a major impact on the typical organization, then almost all managers would be caught off guard. Is it unreasonable to prepare one's mind for such a possibilities? For example, can a scenario be developed where most US consumers would accept higher costs to protect the environment as part of a worldwide green movement? Thinking about this and similar unlikely scenarios is indeed important to developing a flexible executive mindset.

\section{Summary}

Clearly, the above discussion about the implications of the predicted trends is intended to be illustrative not exhaustive. Individual reader/managers, depending on the peculiarities of their industry, will undoubtedly find much to consider based on the other environmental forecasts reported in the tables. The most important lesson is that all managers wishing to cultivate a flexible mindset about the future take the time to ponder periodic environmental scans. These scans can take many forms including forecasts by executive "experts" as was done in this research. The critical point is that managers get in the habit of regularly thinking about the possible impact of change on their organization. Too often, such analysis has been a neglected task. Historically, when it has been done, management has been best at preparing for widely anticipated changes with immediate consequences for their organizations. Far less adroit has been management's analysis of unexpected trends that, at first glance, are not believed to be organizationally consequential. Consistent with Figure 1, these latter situations may imply a need for contingency planning. While it remains true that the future can never be projected with certainty, the military adage, "chance favors the prepared" is abundantly applicable when managing markets for future competitive advantage.

\section{References}

Aaker, D.A. (1992), Strategic Market Management, 3rd ed., John Wiley \& Sons, New York, NY, pp. 243-65.

Journal of Consumer Marketing, Vol 14, No. 1 (1997): pg. 60-81. DOI. This article is $\subset$ Emerald and permission has been granted for this version to appear in e-Publications@Marquette. Emerald does not grant permission for this article to be further copied/distributed or hosted elsewhere without the express permission from Emerald. 
NOT THE PUBLISHED VERSION; this is the author's final, peer-reviewed manuscript. The published version may be accessed by following the link in the citation at the bottom of the page.

Barton, L. (1995), Ethics: The Enemy in the Workplace, Southwestern Publishing, Cincinnati, OH.

Business Week (1995), "Ford: will Alex Trotman's global strategy work?", April 3, pp. 1-8.

Colford, S.W. (1994), "Fade-out for green?", Advertising Age, December 5, pp. $1-8$.

Denton, K.D. (1994), Enviro-Management, Prentice-Hall, Englewood Cliffs, NJ. Fisher, A.B. (1990), "Is long range planning worth it?", Fortune, April 23, pp. 281-4.

Hamel, G.and Prahalad, C.K. (1994a), Competing for the Future, Harvard Business School Press, Boston, MA.

Hamel, G.and Prahalad, C.K. (1994b), "Seeing the future first", Fortune, September 5, pp. 64-70.

Hamel, G.and Prahalad, C.K. (1994c), "Competing for the Future", Harvard Business Review, July-August, pp. 122-28.

Hartley, R.F. (1995), Marketing Mistakes, 6th ed., John Wiley \& Sons, New York, NY.

Hayes, R.H. and Abernathy, W.J. (1980), "Managing our way to economic decline", Harvard Business Review, July-August, pp. 67-77.

Henkoff, R. (1990), "How to plan for 1995", Fortune, December 31, pp. 70-9. Kotler, P. (1994), Marketing Management, 8th ed., Prentice-Hall, Englewood Cliffs, NJ, pp. 17-19 (1994).

Laczniak, G.R. and Lusch, R.F. (1977), "Futures research: a new perspective on corporate planning", Regional Economics and Business, October 1977, pp. 10-15.

Laczniak, G.R. and Lusch, R.F. (1986), "Environment and strategy in 1995: a survey of high level executives", Journal of Consumer Marketing, Spring 1986, pp. 27-45.

Laczniak, G.R., Berkowitz, M.W., Brooker, R.G. and Hale, J.P. (1995), "The ethics of business: improving or deteriorating?", Business Horizons, January- February, pp. 39-47.

Journal of Consumer Marketing, Vol 14, No. 1 (1997): pg. 60-81. DOI. This article is @ Emerald and permission has been granted for this version to appear in e-Publications@Marquette. Emerald does not grant permission for this article to be further copied/distributed or hosted elsewhere without the express permission from Emerald. 
NOT THE PUBLISHED VERSION; this is the author's final, peer-reviewed manuscript. The published version may be accessed by following the link in the citation at the bottom of the page.

Laczniak, G.R., Pecotich, A. and Spadaccini, A. (1994), "Towards 2000: a tougher future for Australian business?", Asia Pacific Journal of Management, April, pp. 67-90.

Levitt, T. (1975), "Marketing myopia 1975: retrospective commentary", Harvard Business Review, September-October.

Modis, T. (1994), "Life cycles: forecasting the rise and fall of almost anything", The Futurist, September-October, pp. 20-5.

Montgomery, D.B. and Weinberg C.B. (1979), "Toward strategic intelligence systems", Journal of Marketing, pp. 41-52.

Murphy, P.E. (1989), "Creating ethical corporate structures", Sloan Management Review, Winter, pp. 81-6.

Olesen, D. (1974), "The future is now: what the heck happened?", The Milwaukee Journal Insight Magazine, February 24, pp. 12-23.

Ottman, J.A. (1992), Green Marketing, NTC Business Books, Lincolnwood, IL.

Schellhardt, T.D. (1991), "More directors are recruited from the outside", The Wall Street Journal, March 20, p. B1.

Schoemaker, P.J.H. (1995), "Scenario planning: a tool for strategic thinking", Sloan Management Review, Winter, pp. 25-40.

Toffler, A. (1970), Future Shock, Random House, New York, NY. Toffler, A. and Toffler, H. (1995), The Politics of the Third Wave, Turner Publishing, Atlanta, GA.

Wilson, I.H. (1978), "Scenarios", in Fowles, J. (Ed.), The Handbook of Future Research, Greenwood Press, Westport, CO.

This summary has been provided to allow managers and executives a rapid appreciation of the content of this article. Those with a particular interest in the topic covered may then read the article in toto to take advantage of the more comprehensive description of the research undertaken and its results to get the full benefit of the material present

Journal of Consumer Marketing, Vol 14, No. 1 (1997): pg. 60-81. DOI. This article is @ Emerald and permission has been granted for this version to appear in e-Publications@Marquette. Emerald does not grant permission for this article to be further copied/distributed or hosted elsewhere without the express permission from Emerald. 
NOT THE PUBLISHED VERSION; this is the author's final, peer-reviewed manuscript. The published version may be accessed by following the link in the citation at the bottom of the page.

\section{Executive summary and implications for managers and executives}

\section{You may be wrong about it but the future matters}

Science fiction writer William Gibson coined the neologism "cyberspace" in his book Neuromancer way back in 1983. This book predicted many of the trends we now see in business and personal telecommunications. Yet, at the same time, Mr Gibson did not predict the single most significant event of the last ten years an event that will have a more profound effect on all our lives than any of the great technological and communications advances. Laczniak and Lusch also refer to this event, commenting that all the detailed and extravagant intelligence and analysis of the US Government failed to predict it. The event was the collapse of the Soviet bloc and the complete discrediting of a philosophy based on a rigorously planned future. As the authors note in referring to noted "futurologists", predictions of the future have a pretty poor track record.

William Gibson cast some light recently on why his predictions succeed in some areas but not in others (Connect @ Telegraph, 19 November 1996). Where the prediction involves extrapolation from things already in place then there is a good chance of them proving accurate (or at least to have some element of truth in them). Where extrapolation does not identify a revolutionary event (such as with the collapse of communism) then the prediction is not accurate. So, when we anticipate what may occur in the future we must act with caution and accept that dramatic events could result in huge unexpected changes and challenges.

Laczniak and Lusch advocate that managers - and especially senior managers - must give more time and attention to the task of crystal ball gazing. Moreover, they demonstrate via their survey that two factors must make up consideration of the future. First, how likely is something to happen, and, second, what impact will something happening have on your business. To take just one example, the EU's proposed single currency: the likelihood of it happening is very high but not 100 percent. However, predicting the precise details of the unification and the countries taking part is a less exact science. Furthermore, the effect on businesses will vary depending on how important European currencies and economies are to their prospects. Clearly, for those businesses reliant on the European market, the single currency will have a major impact, whereas for most US companies it will prove, at worst, a minor irritant.

The challenge for managers, therefore, is to look at the future in a controlled and informed way building on intelligence about the environment to

Journal of Consumer Marketing, Vol 14, No. 1 (1997): pg. 60-81. DOI. This article is @ Emerald and permission has been granted for this version to appear in e-Publications@Marquette. Emerald does not grant permission for this article to be further copied/distributed or hosted elsewhere without the express permission from Emerald. 
NOT THE PUBLISHED VERSION; this is the author's final, peer-reviewed manuscript. The published version may be accessed by following the link in the citation at the bottom of the page.

identify pathways forward. This requires, as Laczniak and Lusch contend, a new managerial mindset and more managerial time. The concept that managers spend at best 3 percent of their time thinking about the future of their businesses seems a depressing reality. After all, when faced with spending a day pondering futures strategies or sorting out a particular problem, what do you do? Like just about everyone, you sort out the problem and cancel the strategy meeting. Also, since you have downsized, there are not the middle managers to take on problem-solving jobs so you have got to do it yourself.

How then do we find the time to think without jeopardizing the smooth operation of the business? We cannot ignore everyday issues to think about the future, since if we do we might not have a business to run in that wonderful future. So we compromise by running an annual think-tank session or a series of away-days. And even there, practical issues (events as former British PM, Harold Macmillan called them) get in the way and dictate discussions. Two modern trends perhaps indicate where this extra time will come from: empowerment and information technology:

(1) The idea of empowerment means that workers do not wait for senior managers to make decisions about their tasks but take on the troubleshooting role themselves. In theory, relieving the senior managers of this day to day management allows them to spend their time on more cerebral, strategic and forward-looking activities.

(2) Information technology not only advances productivity and reduces error rates but makes the task of finding, assessing and analyzing information about a business's environment much simpler. Hopefully managers begin to act on synthesized information about trends without the depressing need to spend time number-crunching or reading great wadges of largely irrelevant data.

These two trends require senior managers to invest in their organizational structures and their information management systems. Without this investment you will not find the time needed to develop a forward-looking mindset.

In concluding, it is not important to review the trends identified by Laczniak and Lusch through a survey of senior managers. In reading them you may or may not agree with the trends' importance and you may feel that other trends such as the erosion of the West's obsession with privacy and secrecy are more important. However, considering what trends are seen as significant can, in many cases, provide important indications as to how to

Journal of Consumer Marketing, Vol 14, No. 1 (1997): pg. 60-81. DOI. This article is $\subset$ Emerald and permission has been granted for this version to appear in e-Publications@Marquette. Emerald does not grant permission for this article to be further copied/distributed or hosted elsewhere without the express permission from Emerald. 
defend your markets or find and attack new ones. Not to study these trends is to stick your head in the sand and wait to die.

Finally, a word of warning. Just because all the great and good believe something is the right thing to do does not make it so. There are too many examples of great sounding ideas which have proved ineffective or worse positively damaging. Be prepared to take the risk of not following the crowd. Remember that thinking about the future is stimulating, exciting at times and, often results in a better understanding of the present.

(A precis of the article "The flexible executive mindset: how top management should look at tomorrow's markets". Supplied by Marketing Consultants for MCB University Press.)

Figure 1. Strategy options for dealing with possible future events

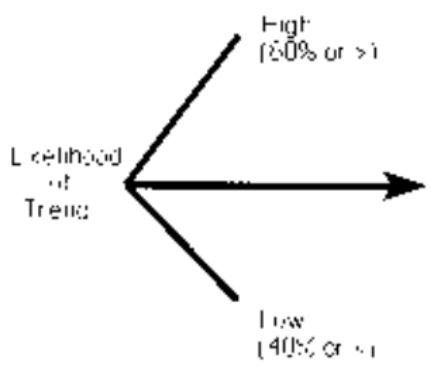

\section{Organizational Impact of Trend}

\begin{tabular}{|c|c|c||}
\hline \multicolumn{1}{|c|}{ High } & Medium & Low \\
\hline $\begin{array}{c}\text { Incorporate } \\
\text { into } \\
\text { Strategic } \\
\text { Plans }\end{array}$ & $\begin{array}{c}\text { Incorporate } \\
\text { into } \\
\text { Strateguc } \\
\text { Plans }\end{array}$ & Monitor \\
\hline $\begin{array}{c}\text { Prepare } \\
\text { Contıngency }\end{array}$ & $\begin{array}{l}\text { Monitor } \\
\text { With } \\
\text { Plan }\end{array}$ & \\
& Optan for & \\
& Contingency & \\
\hline
\end{tabular}

Journal of Consumer Marketing, Vol 14, No. 1 (1997): pg. 60-81. DOI. This article is (C) Emerald and permission has been granted for this version to appear in e-Publications@Marquette. Emerald does not grant permission for this article to be further copied/distributed or hosted elsewhere without the express permission from Emerald. 
NOT THE PUBLISHED VERSION; this is the author's final, peer-reviewed manuscript. The published version may be accessed by following the link in the citation at the bottom of the page.

Table I. World and US economy in 2005 (possible trends)

\section{Item Trend}

E1 Unemployment will exceed 10 percent in most developed countries

E2 There will be major efforts to develop and refine international codes of conduct for multinational corporations

E3 Inflation will exceed 12 percent in most developed countries

E4 Widespread political and financial chaos in less-developed countries will cause worldwide economic instability

E5 A climate of protectionism characterized by periodic international trade wars will result in the formation of regional alliances to increase leverage in world trade

E6 Unrestricted free trade will lead to falling living standards in developed countries as jobs shift from high-wage to low-wage nations

E7 Economic rivalry between the USA and Japan will lead to trade wars

E8 Worldwide global depression will occur

E9 Large corporations will focus heavily on controlling labor costs. Automation (computers, robotics, etc.) will be especially emphasized

E10 Africa will emerge as a continent of choice for multinational corporate investment because of its unexploited natural resources and low-cost labor

E11 Loan defaults by South and Central American countries will cause an international banking crisis

E12 China will emerge as a major economic power

E13 Worldwide sourcing for materials and components will increasingly gravitate to lowcost provider nations

E14 Economic systems around the world will become increasingly alike, evolving into a capitalistic/socialistic hybrid

E15 The standard of living between developed and less developed nations will continue to widen

E16 The number of people working at night will increase as global competition calls for work during hours that match business hours in different international time zones, resulting in "worker wakefulness" concerns

E17 The Pacific Rim countries will exceed the European union in their collective economic power

E18 "Microbusinesses" - entrepreneurial ventures started by people displaced by companies' restructuring - are a strong source of economic growth in the early twenty-first century

E19 By 2005, most Eastern European economies are still too weak to become full-fledged members of the European Economic Community

E20 The US workforce will grow increasingly diverse, as women, minorities, and immigrants account for the majority of new workers during the period 1995-2005

E21 The Dow Jones stock average reaches 10,000 before 2005

E22 Long-term 30-year interest rates in the US fall to 5 percent or lower

E23 Half of US retailers operating in 1994 will be out of business by 2005, because of too many stores, too much leverage, and merchandise homogeneity

E24 The average household income in the USA, adjusted for inflation, will not rise between $1995-2005$

Journal of Consumer Marketing, Vol 14, No. 1 (1997): pg. 60-81. DOI. This article is (C) Emerald and permission has been granted for this version to appear in e-Publications@Marquette. Emerald does not grant permission for this article to be further copied/distributed or hosted elsewhere without the express permission from Emerald. 
NOT THE PUBLISHED VERSION; this is the author's final, peer-reviewed manuscript. The published version may be accessed by following the link in the citation at the bottom of the page.

Table II. World and US economy in 2005 (general perceptions)

\begin{tabular}{|c|c|c|c|c|c|c|c|c|c|c|c|}
\hline \multirow[b]{2}{*}{ Item } & \multirow[b]{2}{*}{$0 \%$} & \multicolumn{6}{|c|}{ Likelihood of occurrence by 2005} & \multicolumn{4}{|c|}{ Organizational impact } \\
\hline & & $20 \%$ & $40 \%$ & $60 \%$ & $80 \%$ & $100 \%$ & Mean \% & High & Medium & Low & Mean $^{\mathrm{a}}$ \\
\hline E1 & 11.3 & 49.1 & 20.8 & 13.2 & 5.7 & 0 & 30.6 & 21.6 & 49 & 29.4 & 2.84 \\
\hline E2 & 3.8 & 32.1 & 26.4 & 20.8 & 13.2 & 3.8 & 43.8 & 7.8 & 43.1 & 49 & 2.17 \\
\hline E3 & 22.6 & 62.3 & 11.3 & 3.8 & 0 & 0 & 19.3 & 46.2 & 40.4 & 13.5 & 3.66 \\
\hline E4 & 7.4 & 63 & 20.4 & 3.7 & 3.7 & 1.9 & 27.8 & 33.3 & 43.1 & 23.5 & 3.19 \\
\hline E5 & 1.9 & 27.8 & 37 & 24.1 & 9.3 & 0 & 42.3 & 32.7 & 46.2 & 21.2 & 3.23 \\
\hline E6 & 16.7 & 50 & 18.5 & 9.3 & 5.6 & 0 & 27.5 & 21.2 & 50 & 28.8 & 2.85 \\
\hline E7 & 3.7 & 53.7 & 20.4 & 14.8 & 7.4 & 0 & 33.7 & 23.1 & 28.8 & 48.1 & 2.5 \\
\hline E8 & 22.2 & 55.6 & 16.7 & 3.7 & 1.9 & 0 & 21.5 & 76.5 & 15.7 & 7.8 & 4.37 \\
\hline$E 9$ & 0 & 7.4 & 20.4 & 25.9 & 25.9 & 20.4 & 66.3 & 43.1 & 54.9 & 2 & 3.82 \\
\hline E10 & 31.5 & 48.1 & 13 & 5.6 & 1.9 & 0 & 19.7 & 1.9 & 26.9 & 71.2 & 1.61 \\
\hline E11 & 13 & 57.4 & 24.1 & 3.7 & 1.9 & 0 & 24.9 & 7.8 & 37.3 & 54.9 & 2.06 \\
\hline E12 & 0 & 11.1 & 16.7 & 29.6 & 31.5 & 11.1 & 63 & 30.8 & 48.1 & 21.2 & 3.2 \\
\hline E13 & 0 & 3.7 & 22.2 & 40.7 & 31.5 & 1.9 & 61.1 & 21.2 & 55.8 & 23.1 & 2.97 \\
\hline E14 & 3.8 & 22.6 & 32.1 & 26.4 & 13.2 & 1.9 & 45.7 & 13.7 & 56.9 & 29.4 & 2.69 \\
\hline E15 & 1.9 & 20.4 & 38.9 & 25.9 & 13 & 0 & 45.6 & 7.7 & 36.5 & 55.8 & 2.04 \\
\hline E16 & 7.4 & 42.6 & 22.2 & 18.5 & 9.3 & 0 & 35.9 & 5.8 & 32.7 & 61.5 & 1.89 \\
\hline E17 & 0 & 9.3 & 27.8 & 31.5 & 18.5 & 13 & 59.7 & 26.9 & 48.1 & 25 & 3.04 \\
\hline E18 & 0 & 27.8 & 22.2 & 27.8 & 18.5 & 3.7 & 49.6 & 15.4 & 36.5 & 48.1 & 2.35 \\
\hline E19 & 1.9 & 18.5 & 25.9 & 31.5 & 16.7 & 5.6 & 51.9 & 1.9 & 40.4 & 57.7 & 1.88 \\
\hline E20 & 0 & 0 & 11.1 & 22.2 & 44.4 & 22.2 & 75.5 & 40.4 & 46.2 & 13.5 & 3.54 \\
\hline E21 & 3.9 & 33.3 & 25.5 & 23.5 & 13.7 & 0 & 41.9 & 36.7 & 32.7 & 30.6 & 3.12 \\
\hline E22 & 18.9 & 49.1 & 20.8 & 5.7 & 5.55 & 0 & 26.1 & 39.2 & 45.1 & 15.7 & 3.47 \\
\hline E23 & 11.3 & 28.3 & 30.2 & 18.9 & 9.4 & 1.9 & 38.5 & 17.3 & 26.9 & 55.8 & 2.23 \\
\hline E24 & 5.6 & 33.3 & 24.1 & 13 & 22.2 & 1.9 & 43.8 & 23.1 & 51.9 & 25 & 2.96 \\
\hline
\end{tabular}

Note: " Five-point scale where $1=$ low organizational impact and $5=$ high organizational impact

Journal of Consumer Marketing, Vol 14, No. 1 (1997): pg. 60-81. DOI. This article is @ Emerald and permission has been granted for this version to appear in e-Publications@Marquette. Emerald does not grant permission for this article to be further copied/distributed or hosted elsewhere without the express permission from Emerald. 
NOT THE PUBLISHED VERSION; this is the author's final, peer-reviewed manuscript. The published version may be accessed by following the link in the citation at the bottom of the page.

Table III. Technology in 2005 (possible trends)

\section{Item Trend}

T1 Increasingly powerful and inexpensive microcomputers will make possible highly comprehensive interlocking data banks

T2 The telecommunications, information and electronics industries will continue their ascendance

T3 Twenty-five percent of retail sales will occur via in-home computer terminals or interactive television

T4 The majority of manufacturing facilities in developed countries will have moved to significantly greater automation via computerized machine tools, robotic systems and $\mathrm{CAD} / \mathrm{CAM}$

T5 There will be a prevailing climate of social and ethical problems caused by advancing technology

T6 Advanced electronic manufacturing systems which require workers with better education and more training will engender a labor shortage of qualified workers

T7 The promise of biogenetic technology will finally emerge with a regular stream of new pharmaceuticals having a significant effect on the quality of life in developed countries

T8 Space missions will provide a major economic boost to R\&D in corporations with high technology operations

T9 Interlocking computer systems and databases will provide managers with the information to improve productivity by 15 percent

T10 Eighty percent of individuals under age 30 in developed countries will be computer competent

T11 A checkbook-sized, wireless communication devise incorporating cellular phone, fax, and e-mail capability will be used by one-third of professional managers

T12 Personal computers will be as powerful as today's mainframe computers

T13 High-speed rail systems will operate on several heavily travelled routes in the United States whisking millions of travelers a year out of gridlocked airports and highways

T14 Fifty percent of US households have fax machines

T15 Artificial intelligence (AI) will increasingly be used for middle management decision making. AID will affect 25 percent of the jobs in large organizations, augmenting, displacing, downgrading, and eliminating workers

T16 Information "superhighways" link scientists, business people, educators and the general public together

T17 The increased use of robots, $\mathrm{CAD} / \mathrm{CAM}$, and flexible manufacturing complexes allows many companies to cut their workforces by one-third

T18 Computers and related technologies will replace teachers and significantly increase the opportunities for non school-based education and employee training

T19 Security will be one of the fastest-growing business sectors of the twenty-first century, as the "haves" increasingly seek to remove, and protect themselves and their property, from the "have-nots"

T20 Virtual reality and computer simulation will become a major element of higher education and worker training

T21 Medical procedures based on genetic engineering will account for over 10 percent of medial spending

Journal of Consumer Marketing, Vol 14, No. 1 (1997): pg. 60-81. DOI. This article is @ Emerald and permission has been granted for this version to appear in e-Publications@Marquette. Emerald does not grant permission for this article to be further copied/distributed or hosted elsewhere without the express permission from Emerald. 
NOT THE PUBLISHED VERSION; this is the author's final, peer-reviewed manuscript. The published version may be accessed by following the link in the citation at the bottom of the page.

Table IV. Technology in 2005 (general perceptions)

\begin{tabular}{lcrrrrrrrrrrrr}
\hline \multicolumn{1}{c}{ Likelihood of occurrence by 2005} & \multicolumn{4}{c}{ Organizational impact } \\
Item & $0 \%$ & $20 \%$ & $40 \%$ & $60 \%$ & $80 \%$ & $100 \%$ & Mean $\%$ & High & Medium & Low & Mean $^{\text {a }}$ \\
& & & & & & & & & & & & & \\
T1 & 0 & 1.9 & 5.6 & 13 & 46.3 & 33.3 & 80.8 & 44.2 & 50 & 5.8 & 3.8 \\
T2 & 0 & 0 & 3.8 & 15.1 & 43.4 & 37.7 & 83.0 & 45.1 & 51 & 3.9 & 3.8 \\
T3 & 3.8 & 30.2 & 18.9 & 32.1 & 9.4 & 5.7 & 46.1 & 23.5 & 33.3 & 43.1 & 2.6 \\
T4 & 0 & 5.6 & 22.2 & 27.8 & 24.1 & 20.4 & 66.4 & 25 & 40.4 & 34.6 & 2.8 \\
T5 & 0 & 33.3 & 16.7 & 22.2 & 25.9 & 1.9 & 49.3 & 17.3 & 36.5 & 46.2 & 2.4 \\
T6 & 0 & 1.9 & 24.1 & 40.7 & 25.9 & 7.4 & 62.6 & 40.4 & 51.9 & 7.7 & 3.7 \\
T7 & 1.9 & 18.9 & 11.3 & 20.8 & 37.7 & 9.4 & 60.3 & 19.6 & 25.5 & 54.9 & 2.3 \\
T8 & 13 & 48.1 & 18.5 & 5.6 & 14.8 & 0 & 32.2 & 13.5 & 11.5 & 75 & 1.8 \\
T9 & 3.7 & 14.8 & 18.5 & 18.5 & 27.8 & 16.7 & 60.4 & 48.1 & 42.3 & 9.6 & 3.8 \\
T10 & 3.7 & 7.4 & 11.1 & 25.9 & 33.3 & 18.5 & 66.6 & 38.5 & 48.1 & 13.5 & 3.5 \\
T11 & 1.9 & 16.7 & 13 & 18.5 & 42.6 & 7.4 & 61.1 & 23.5 & 39.2 & 37.3 & 2.7 \\
T12 & 1.9 & 9.4 & 9.4 & 5.7 & 37.7 & 35.8 & 75.0 & 41.2 & 47.1 & 11.8 & 3.6 \\
T13 & 16 & 38.9 & 14.8 & 14.8 & 7.4 & 7.4 & 35.9 & 17.6 & 25.5 & 56.9 & 2.2 \\
& 7 & & & & & & & & & & \\
T14 & 5.7 & 26.4 & 20.8 & 17 & 20.8 & 9.4 & 49.8 & 0 & 39.2 & 60.8 & 1.8 \\
T15 & 9.4 & 39.6 & 22.6 & 18.9 & 7.5 & 1.9 & 36.2 & 17.6 & 56.9 & 25.5 & 2.8 \\
T16 & 1.9 & 11.1 & 16.7 & 20.4 & 22.2 & 27.8 & 66.7 & 30.8 & 50 & 19.2 & 3.2 \\
T17 & 1.9 & 28.3 & 22.6 & 24.5 & 17 & 5.7 & 48.7 & 33.3 & 41.2 & 25.5 & 3.2 \\
T18 & 3.7 & 22.2 & 33.3 & 24.1 & 9.3 & 7.4 & 47.1 & 15.4 & 40.4 & 44.2 & 2.4 \\
T19 & 3.7 & 16.7 & 20.4 & 24.1 & 22.2 & 13 & 56.7 & 13.5 & 44.2 & 42.3 & 2.4 \\
T20 & 0 & 15.1 & 18.9 & 24.5 & 32.1 & 9.4 & 60.4 & 13.7 & 56.9 & 29.4 & 2.7 \\
T21 & 1.9 & 34.6 & 21.2 & 17.3 & 17.3 & 7.7 & 47.3 & 10 & 22 & 68 & 1.8 \\
& & & & & & & & & & &
\end{tabular}

Note: a Five-point scale where $1=$ low organizational impact and $5=$ high organizational impact 
NOT THE PUBLISHED VERSION; this is the author's final, peer-reviewed manuscript. The published version may be accessed by following the link in the citation at the bottom of the page.

Table V. World and US ecology in 2005 (possible trends)

Item Trend

G1 There will be increased global pollution

G2 Worldwide shortages of food will occur

G3 Worldwide shortages of oil will occur

G4 Significant fresh water shortages will develop

G5 The greenhouse effect will lead to several ecological crises (e.g. coastal flooding, agricultural disruption)

G6 Consumers will accept higher costs in order to protect the environment

G7 Fish farming and aqua-agriculture (ocean farming) will produce sufficient high protein food as to significantly alleviate food shortages

G8 There will be increasing international pressure, including sanctions to influence the environmental policies of certain countries (e.g. Brazil's development of the Amazon rain forests)

G9 World population will continue to expand rapidly causing famine in Third-World countries

G10 Biotechnology and related yield-increasing developments will account for 80 percent of the growth in world harvests in 2005

G11 New environmental restrictions in the USA will significantly damage the competitiveness of US business

G12 A worldwide market will develop in "rights to pollute" licenses

G13 The green marketing movement will lead to a host of ecologically compatible products and promotional appeals. Such products will dominate a number of product categories by 2005

Journal of Consumer Marketing, Vol 14, No. 1 (1997): pg. 60-81. DOI. This article is $\subset$ Emerald and permission has been granted for this version to appear in e-Publications@Marquette. Emerald does not grant permission for this article to be further copied/distributed or hosted elsewhere without the express permission from Emerald. 
NOT THE PUBLISHED VERSION; this is the author's final, peer-reviewed manuscript. The published version may be accessed by following the link in the citation at the bottom of the page.

Table VI. World and US ecology in 2005 (general perceptions)

\begin{tabular}{lrrrrrlllllll}
\hline \multicolumn{1}{c}{ Likelihood of occurrence by 2005} & \multicolumn{4}{c}{ Organizational impact } \\
Item & $0 \%$ & $20 \%$ & $40 \%$ & $60 \%$ & $80 \%$ & $100 \%$ & Mean $\%$ & High & Medium & Low & Mean $^{\mathrm{a}}$ \\
\hline & & & & & & & & & & & \\
G1 & 1.9 & 28.3 & 17 & 15.1 & 22.6 & 15.1 & 54.7 & 21.2 & 28.8 & 50 & 2.42 \\
G2 & 29.6 & 38.9 & 14.8 & 9.3 & 5.6 & 1.9 & 25.7 & 25 & 15.4 & 59.6 & 2.31 \\
G3 & 11.1 & 46.3 & 20.4 & 7.4 & 7.4 & 7.4 & 35.2 & 48.1 & 23.1 & 28.8 & 3.39 \\
G4 & 9.3 & 29.6 & 25.9 & 18.5 & 9.3 & 7.4 & 42.2 & 23.1 & 32.7 & 44.2 & 2.58 \\
G5 & 38.9 & 40.7 & 11.1 & 1.9 & 7.4 & 0 & 19.6 & 19.2 & 34.6 & 46.2 & 2.46 \\
G6 & 5.6 & 31.5 & 22.2 & 18.5 & 13 & 9.3 & 46 & 17.3 & 34.6 & 48.1 & 2.38 \\
G7 & 9.4 & 30.2 & 30.2 & 22.6 & 7.5 & 0 & 37.7 & 5.9 & 17.6 & 76.5 & 1.59 \\
G8 & 1.9 & 20.8 & 20.8 & 32.1 & 18.9 & 5.7 & 52.6 & 7.8 & 31.4 & 60.8 & 1.94 \\
G9 & 9.3 & 25.9 & 14.8 & 20.4 & 20.4 & 9.3 & 49 & 11.5 & 23.1 & 65.4 & 1.92 \\
G10 & 5.8 & 25 & 28.8 & 19.2 & 15.4 & 5.8 & 46.2 & 12 & 20 & 68 & 1.88 \\
G11 & 3.7 & 33.3 & 20.4 & 14.8 & 16.7 & 11.1 & 48.2 & 48.1 & 32.7 & 19.2 & 3.58 \\
G12 & 9.4 & 49.1 & 15.1 & 18.9 & 5.7 & 1.9 & 33.7 & 22 & 24 & 54 & 2.36 \\
G13 & 3.8 & 30.2 & 30.2 & 18.9 & 17 & 0 & 43.1 & 7.8 & 37.3 & 54.9 & 2.06 \\
& & & & & & & & & & &
\end{tabular}

Note: ${ }^{\text {a }}$ Five-point scale where $1=$ low organizational impact and $5=$ high organizational impact

Journal of Consumer Marketing, Vol 14, No. 1 (1997): pg. 60-81. DOI. This article is @ Emerald and permission has been granted for this version to appear in e-Publications@Marquette. Emerald does not grant permission for this article to be further copied/distributed or hosted elsewhere without the express permission from Emerald. 
NOT THE PUBLISHED VERSION; this is the author's final, peer-reviewed manuscript. The published version may be accessed by following the link in the citation at the bottom of the page.

Table VII. US social environment in 2005 (possible trends)

Item Trend

S1 An infrastructure crisis (affecting roads, schools, public services) will occur in many US cities

S2 The quality of public education at all levels will be a major concern throughout the first decade of the twenty-first century

S3 Corporate programs involving worker benefits such as on-site child care, flexible working hours, child rearing leaves and sick leave for family illnesses will be pervasive

S4 The US labor force will become increasingly stratified into two tiers: the technological élites and a more common underclass of relatively low-paid clerical and services workers

S5 The AIDS epidemic will cost billions of dollars in health costs and lost productivity

S6 Social friction between employees and the elderly will increase significantly because younger employees perceive that they are paying too big a percentage of the costs for elderly entitlement programs (e.g. social security, medicare, etc.)

S7 The American workforce will become less interested in job performance and more interested in job satisfaction

S8 Lifelong continuing education requirements for management will require corporate commitment of at least ten days per year per manager toward this effort

S9 US high-school students will have to be prepared to change jobs and/or careers at least five times during their lifetimes

S10 Employee participation in management, as reflected in ESOPs, employee board of directors representation and worker-management councils, will be significantly more widespread than presently

S11 Shopping vacations become increasingly popular as consumer travel to regional outlet centers for bargains and amusement-park-like mega malls for recreation

S12 Employers' access to knowledge about their employees' genetic susceptibility to disease becomes one of the largest organizational privacy questions of the next century

S13 Information services will not only allow people to commute to work electronically, but engage in many other social functions via computer, such as electronic shopping, banking, trading securities, voting, getting physical check-ups, and undergoing psychotherapy

S14 Health-related occupations will comprise seven out of ten of the fastest-growing jobs in the USA in the next decade

S15 In-home entertainment, such as cable television, CD-ROM and video sales/rentals, will grow far faster than theater or sports attendance in the years between 1995-2005

S16 As the baby boomers age, they will revitalize numerous industries with their purchases such as security systems, home entertainment, housekeeping services, home health care, vitamins, anti-aging cosmetics, travel services, investment advice, and adult education

S17 Socially responsible businesses will thrive in the future as consumers seek out companies that operate with ethics and integrity

S18 The percentage of new US college graduates securing a job that requires a college degree will decrease by 25 per cent or more in the next ten years

Journal of Consumer Marketing, Vol 14, No. 1 (1997): pg. 60-81. DOI. This article is $\subset$ Emerald and permission has been granted for this version to appear in e-Publications@Marquette. Emerald does not grant permission for this article to be further copied/distributed or hosted elsewhere without the express permission from Emerald. 
NOT THE PUBLISHED VERSION; this is the author's final, peer-reviewed manuscript. The published version may be accessed by following the link in the citation at the bottom of the page.

Table VIII. US social environment in 2005 (general perceptions)

\begin{tabular}{llccccccccccc}
\hline \multicolumn{1}{c}{ Likelihood of occurrence by 2005} & \multicolumn{5}{c}{ Organizational impact } \\
Item & $0 \%$ & $20 \%$ & $40 \%$ & $60 \%$ & $80 \%$ & $100 \%$ & Mean $\%$ & High & Medium Low & Mean \\
\hline S1 & 1.9 & 16.7 & 16.7 & 29.6 & 24.1 & 11.1 & 58.2 & 27.5 & 51 & 21.6 & 3.12 \\
S2 & 0 & 1.9 & 9.3 & 9.3 & 38.9 & 40.7 & 81.5 & 40.4 & 46.2 & 13.5 & 3.54 \\
S3 & 1.9 & 7.5 & 18.9 & 18.9 & 37.7 & 15.1 & 65.7 & 30.8 & 59.6 & 9.6 & 3.42 \\
S4 & 0 & 14.8 & 22.2 & 24.1 & 22.2 & 16.7 & 60.8 & 36.5 & 46.2 & 17.3 & 3.38 \\
S5 & 0 & 18.5 & 14.8 & 11.1 & 37 & 18.5 & 64.4 & 23.1 & 32.7 & 44.2 & 2.58 \\
S6 & 3.7 & 11.1 & 35.2 & 20.4 & 20.4 & 9.3 & 54.2 & 15.4 & 44.2 & 40.4 & 2.5 \\
S7 & 5.6 & 14.8 & 31.5 & 18.5 & 20.4 & 9.3 & 52.3 & 36.5 & 46.2 & 17.3 & 3.38 \\
S8 & 7.4 & 20.4 & 16.7 & 16.7 & 25.9 & 13 & 54.5 & 26.9 & 53.8 & 19.2 & 3.15 \\
S9 & 0 & 5.6 & 16.7 & 25.9 & 24.1 & 27.8 & 70.4 & 23.1 & 50 & 26.9 & 2.92 \\
S10 & 3.8 & 18.9 & 26.4 & 34 & 9.4 & 7.5 & 49.8 & 15.7 & 49 & 35.3 & 2.61 \\
S11 & 9.3 & 46.3 & 14.8 & 22.2 & 3.7 & 3.7 & 35.2 & 1.9 & 19.2 & 78.8 & 1.46 \\
S12 & 9.3 & 37 & 22.2 & 14.8 & 14.8 & 1.9 & 38.9 & 11.5 & 36.5 & 51.9 & 2.19 \\
S13 & 0 & 16.7 & 13 & 18.5 & 31.5 & 20.4 & 65.2 & 26.9 & 42.3 & 30.8 & 2.92 \\
S14 & 1.9 & 26.4 & 32.1 & 24.5 & 11.3 & 3.8 & 45.7 & 13.7 & 27.5 & 58.8 & 2.1 \\
S15 & 0 & 13.2 & 13.2 & 32.1 & 26.4 & 15.1 & 63.4 & 7.8 & 19.6 & 72.5 & 1.7 \\
S16 & 0 & 5.6 & 14.8 & 25.9 & 38.9 & 14.8 & 68.5 & 13.5 & 34.6 & 51.9 & 2.23 \\
S17 & 5.6 & 25.9 & 22.2 & 27.8 & 14.8 & 3.7 & 46.3 & 19.2 & 38.5 & 42.3 & 2.54 \\
S18 & 16.7 & 38.9 & 18.5 & 18.5 & 7.4 & 0 & 32.2 & 11.5 & 36.5 & 51.9 & 2.19 \\
& & & & & & & & & & &
\end{tabular}

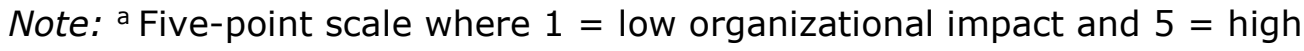
organizational impact

Journal of Consumer Marketing, Vol 14, No. 1 (1997): pg. 60-81. DOI. This article is @ Emerald and permission has been granted for this version to appear in e-Publications@Marquette. Emerald does not grant permission for this article to be further copied/distributed or hosted elsewhere without the express permission from Emerald. 
NOT THE PUBLISHED VERSION; this is the author's final, peer-reviewed manuscript. The published version may be accessed by following the link in the citation at the bottom of the page.

Table IX. US political environment in 2005 (possible trends)

Item Trend

P1 The USA adopts an industrial policy whereby the federal government assists key industries to be world competitive

P2 Referenda will be increasingly used to poll the public concerning controversial national issues

P3 Substantially increased federal regulation of domestic US business

P4 There will be a continued movement toward the use of more outside directors that represent stakeholder groups such as labor, consumers, the community, etc.

P5 The elderly (65 and over) will accrue increased political power

P6 The USA enacts measures which severely restrict foreign investment in the USA

P7 Labor unions will continue to lose political power

P8 Compulsory national service for young Americans is required

P9 Military "right-sizing" frees up federal government monies for other uses

P10 Information litigation - copyright disputes, patent infringements, industrial espionage, owners of personal information in data files - will increasingly fill the dockets of domestic and international courts

P11 Substantially increased environmental regulation (on clean air, acid rain, dump sites, oil spills, etc.) by federal, state, and local government

P12 Foreign ownership of US real estate and financial securities will further complicate the ability to control the US economy

P13 The US federal government will enact a value-added tax (VAT)

P14 Increased political friction occurs between US states that have achieved high growth economies and those states that face economic depression

P15 New ethical dilemmas are raised about the allocation of health care in the US. Ethics committees will be formed in order to deal with these

P16 As religious, ethnic, and cultural groups clash with greater regularity and passion, the frequency of international terrorism increases

P17 The personal healthcard issued to citizens as part of US health-care reform will increasingly function as a national ID card

P17 The personal healthcard issued to citizens as part of US health-care reform will increasingly function as a national ID card

P18 A compulsory second language is introduced into public primary and secondary school curriculums

P19 Greater-than-expected costs in federally funded health care will force more health rationing and public dissatisfaction than anticipated

P20 There is a legislative backlash to legalized gambling as society increasingly realizes the social problems it causes (e.g. disproportionate spending by poor, addictiveness, etc.)

Journal of Consumer Marketing, Vol 14, No. 1 (1997): pg. 60-81. DOI. This article is @ Emerald and permission has been granted for this version to appear in e-Publications@Marquette. Emerald does not grant permission for this article to be further copied/distributed or hosted elsewhere without the express permission from Emerald. 
NOT THE PUBLISHED VERSION; this is the author's final, peer-reviewed manuscript. The published version may be accessed by following the link in the citation at the bottom of the page.

Table X. US politicial environment in 2005 (general perceptions)

\begin{tabular}{lcccccccccccc}
\hline \multicolumn{1}{c}{ Likelihood of occurrence by 2005} & \multicolumn{4}{c}{ Organizational impact } \\
Item & $0 \%$ & $20 \%$ & $40 \%$ & $60 \%$ & $80 \%$ & $100 \%$ & Mean $\%$ & High & Medium Low & Mean \\
& & & & & & & & & & \\
\hline P1 & 5.6 & 46.3 & 20.4 & 9.3 & 13 & 5.6 & 39 & 34.6 & 34.6 & 30.8 & 3.08 \\
P2 & 3.7 & 25.9 & 25.9 & 20.4 & 16.7 & 7.4 & 48.5 & 11.5 & 30.8 & 57.5 & 2.07 \\
P3 & 5.6 & 24.1 & 24.1 & 13 & 14.8 & 18.5 & 52.6 & 61.5 & 28.8 & 9.6 & 4.04 \\
P4 & 0 & 14.8 & 20.4 & 37 & 18.5 & 9.3 & 57.4 & 23.5 & 51 & 25.5 & 2.96 \\
P5 & 1.9 & 3.7 & 11.1 & 20.4 & 44.4 & 18.5 & 71.4 & 11.5 & 38.5 & 50 & 2.23 \\
P6 & 24.1 & 51.9 & 7.4 & 11.1 & 3.7 & 1.9 & 24.9 & 23.1 & 36.5 & 40.4 & 2.65 \\
P7 & 0 & 9.3 & 13 & 29.6 & 29.6 & 18.5 & 67 & 15.4 & 38.5 & 46.2 & 2.39 \\
P8 & 27.8 & 42.6 & 14.8 & 13 & 1.9 & 0 & 23.8 & 1.9 & 15.4 & 82.7 & 1.38 \\
P9 & 11.1 & 25.9 & 24.1 & 16.7 & 18.5 & 3.7 & 43.3 & 7.7 & 26.9 & 65.4 & 1.85 \\
P10 & 0 & 7.4 & 22.2 & 24.1 & 27.8 & 18.5 & 65.6 & 13.5 & 42.3 & 44.2 & 2.39 \\
P11 & 0 & 13 & 18.5 & 20.4 & 22.2 & 25.9 & 65.9 & 50 & 32.7 & 17.3 & 3.65 \\
P12 & 9.3 & 25.9 & 24.1 & 11.1 & 20.4 & 9.3 & 47.1 & 7.7 & 44.2 & 48.1 & 2.19 \\
P13 & 5.7 & 18.9 & 30.2 & 20.8 & 17 & 7.5 & 49.4 & 35.3 & 45.1 & 19.6 & 3.31 \\
P14 & 1.9 & 31.5 & 35.2 & 9.3 & 18.5 & 3.7 & 44.5 & 9.6 & 28.8 & 61.5 & 1.96 \\
P15 & 0 & 22.2 & 18.5 & 31.5 & 20.4 & 7.4 & 54.5 & 11.5 & 40.4 & 48.1 & 2.27 \\
P16 & 1.9 & 27.8 & 13 & 25.9 & 25.9 & 5.6 & 52.6 & 17.3 & 34.6 & 48.1 & 2.38 \\
P17 & 9.4 & 32.1 & 5.7 & 32.1 & 11.3 & 9.4 & 46.4 & 7.8 & 37.3 & 54.9 & 2.06 \\
P18 & 33.3 & 25.9 & 16.7 & 18.5 & 5.6 & 0 & 27.4 & 3.8 & 25 & 71.2 & 1.65 \\
P19 & 0 & 15.1 & 11.3 & 17 & 28.3 & 28.3 & 68.7 & 29.4 & 43.1 & 27.5 & 3.04 \\
P20 & 7.4 & 35.2 & 27.8 & 14.8 & 13 & 1.9 & 39.3 & 0 & 11.5 & 88.5 & 1.23 \\
& & & & & & & & & & &
\end{tabular}

Note: ${ }^{\text {a }}$ Five-point scale where $1=$ low organizational impact and $5=$ high organizational impact

Journal of Consumer Marketing, Vol 14, No. 1 (1997): pg. 60-81. DOI. This article is @ Emerald and permission has been granted for this version to appear in e-Publications@Marquette. Emerald does not grant permission for this article to be further copied/distributed or hosted elsewhere without the express permission from Emerald. 